\title{
Prevalence of Fish and Shrimp Diseases and Use of Various Drugs and Chemicals in Indian Aquaculture for Disease Management
}

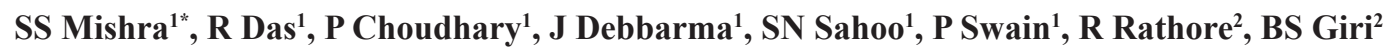 \\ ${ }^{1}$ Fish Health Management Division, ICAR-Central Institute of Freshwater Aquaculture (CIFA), Kausalyaganga, Bhubaneswar, Odisha, \\ India
}

${ }^{2}$ Regional Centre of ICAR-Central Institute of Freshwater Aquaculture, Poranki, Vijayawada, Andhra Pradesh, India

"Corresponding author: SS Mishra, Fish Health Management Division, ICAR-Central Institute of Freshwater Aquaculture (CIFA), Kausalyaganga, Bhubaneswar-751002, Odisha, India. Tel: +917894281261; Email: ss_mishra60@yahoo.co.uk

Citation: Mishra SS, Das R, Choudhary P, Debbarma J, Sahoo SN, et al. (2017) Prevalence of Fish and Shrimp Diseases and Use of Various Drugs and Chemicals in Indian Aquaculture for Disease Management. J Fish Aqua Dev: JFAD-129. DOI:10.29011/JFAD$129 / 100029$

Received Date: 24 October, 2017; Accepted Date: 3 November, 2017; Published Date: 13 November, 2017

\begin{abstract}
There has been serious concern by different national and international organizations over misuse or abuse of drugs, chemicals and antibiotics, which often lead to development of Antimicrobial Resistance (AMR) and aquaculture has drawn the attention. The present survey was carried out to understand prevalence of different fish and shrimp disease in different culture conditions as adopted by different farmers and use of various commercially available aqua-medicines, drugs and chemicals in aquaculture activities in the selected zones of four aquaculture dominant states of India viz., Andhra Pradesh, Odisha, Jharkhand and Chhattisgarh. Information on a total of 406 aqua-drugs, chemicals, antibiotics and microbial formulations were collected with maximum of 242 from Andhra Pradesh, 118 from Odisha, 36 from Jharkhand and 30 from Chhattisgarh. These drugs belonged to six main categories like water quality management products (Sanitizers), anti-parasitic drugs, Antiseptics and disinfectants, Antibiotics, Microbial bioremediation products and Feed supplements and growth promoters. These products were used mainly in shrimp culture and to a lesser extent in fish culture. Highest proportion of products used in aquaculture was chemicals for water quality treatment followed by antiseptics and disinfectants, Microbial water remediation products and Antiparasitic drugs. Only 4-8 antibiotics commercial brands were available in the market for use in aquaculture. Local consultants played a major role in supplying these aquaculture medicines, drugs and chemicals to the farms on an agreement basis and some farmers even not had sufficient knowledge about the products they use in their farms, their method of application and impact. Significantly, some farmers in Andhra Pradesh and Odisha have developed and used innovative method of organic aquaculture, without addition of any chemicals, drugs or chemical fertilizers with successful harvest, while some farmers in Jharkhand and Chhattisgarh have adopted modified semi-intensive method of culture without much requirement of drugs and chemicals in fish culture. While drug use in aquaculture has decreased in recent years, there are some anthropogenic activities which have led to release of large quantities of drugs, chemicals, pesticides and antibiotics into aquatic system, mainly through human wastes and agricultural runoff, thereby impacting aquatic lives. It is hoped that early implementation of "National aquaculture Policy" would help in a long way to control such menace and support sustainable development of aquaculture sector in India.
\end{abstract}




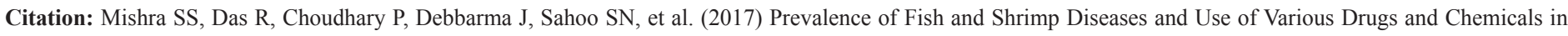
Indian Aquaculture for Disease Management. J Fish Aqua Dev: JFAD-129. DOI: 10.29011/JFAD-129. 100029

Keywords: Aquaculture; Aqua-medicines; Antibiotics; Chemicals; Drugs; Fish culture; Shrimp farming

\section{Introduction}

The aquaculture sector in India has shown continuous growth and has contributed significantly to global aquaculture production. While, Asia contributes more than $90 \%$ to the world's aquaculture production, India now takes the second position with regard to annual fisheries and aquaculture production, only after China [1] and the country contributes to about $7.3 \%$ of the global aquaculture production [2]. India harbours more than $10 \%$ of global fish biodiversity [3] and more than 14.5 million people are directly or indirectly dependant on fisheries and aquaculture their livelihood security [4]. Significant growth of fishery sector is shown by enhancement in fish production from 7.5 lakh tonnes in 1950-51 to 107.95 lakh tonnes during 2015-16 [3,5]. Freshwater aquaculture sector contributes about $85 \%$ of the inland share. The majority of aquaculture production of fish, crustaceans and molluscs continues to come from the freshwater environment $(57.7 \%$ by volume and $48.4 \%$ by value) [6]. The largest area under aquaculture being in the state of Andhra Pradesh (0.52mha), followed by Karnataka (0.41 mha) and West Bengal (0.276mha). These three states account for about $50.5 \%$ of India's aquaculture areas. Brackish water aquaculture includes culture of shrimp varieties mainly, the native giant tiger prawn (Penaeus monodon) and exotic white leg shrimp (Penaeus vannamei). About $90 \%$ of the shrimp farmers in India are small scale farmers which own less than 2 ha of land [1,7]. Brackish water shrimp farming sector in India has witnessed significant transformation over the last three decades. Data indicates a total of 68846 ha area is under tiger shrimp culture in 9 maritime states producing 81452 MT with an average production of 1.18 MT/ha/year. Andhra Pradesh state has been the hub of modern aquaculture and the production trends in this state reflect directly in the country's production $[3,8]$. Shrimp production data indicates nearly five times enhancement of shrimp production during last 15 years with a mere production of less than 100,000 metric tonnes during 2000-01 to around 500,000 metric tonnes during 2015-16 [9] (Figure 1).

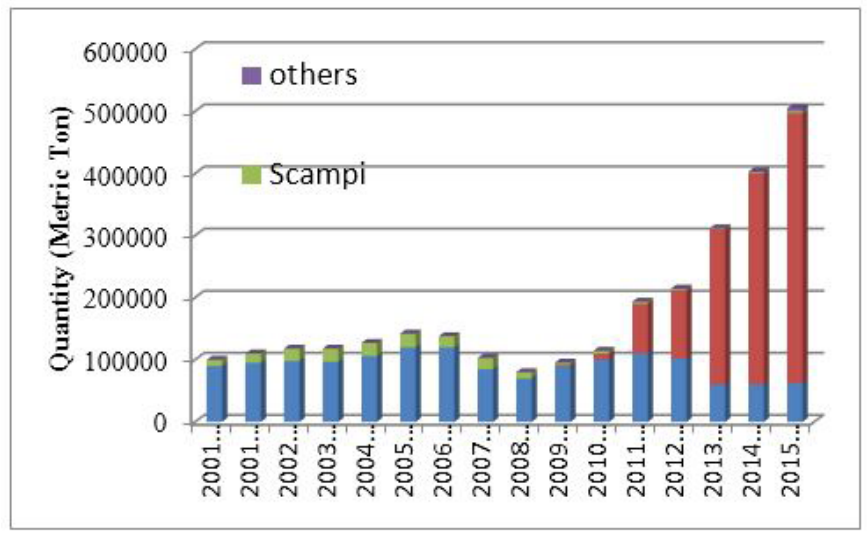

Figure 1: Showing development of shrimp aquaculture production in India, with variable composition of species during last 15 years (Adapted with modification from: Aqua Aquaria India 2017 [9], and Mishra et al., 2017c) [10].

There has been significant shift from primarily tiger shrimp $P$. monodon production to predominant $P$. vennamei production to more than $80 \%$ of total shrimp production. Similarly, there has been significant foreign exchange earing through export of frozen shrimp at International market with earning value of 2000 billion INR during 2015-16 (Figure 2).

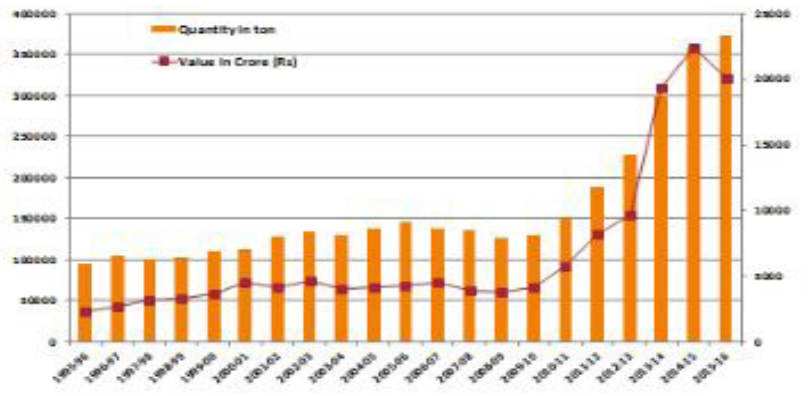

Figure 2: Showing export of frozen shrimp (in tone's) at international market with earning of foreign exchange (Source: MPEDA, 2017) [8]. 
Despite phenomenal growth of aquaculture sector both in fish and shrimp production during last few years, the progress of aquaculture has caused some unwarranted activities including emergence and spread of diseases in aquaculture adversely affecting growth of the sector [11]. The total loss to aquaculture sector world-wide has been estimated to be more than US\$ 6.0 billion per anum [2]. To protect cultured fish and shrimp, farmers are in practice of using a wide range of aqua-medicines, drugs and chemicals in aquaculture to control production loss. Besides aquaculture drugs and chemicals are also used in pond construction, soil and water management, enhancement of natural aquatic productivity, feed formulation, manipulation of reproduction, growth promotion and processing and value addition of the final product [12-14]. Since many countries like India do not have specific regulations and guidelines on use of drugs and chemicals in fisheries and aquaculture unlike FDA rules for human and animal medicine, diverse chemicals and drugs even those in veterinary practices and agriculture crop management are freely being used in aquaculture. Hence, serious concern has been raised by different international organizations like FAO and OIE on irresponsible use of drugs and antibiotics, which often can lead to development of Antimicrobial Resistance (AMR) [16]. The amount of information on chemical use in aquaculture and its significance for human health assurance, environmental protection and sustainable development of the sector, has been increasing. Although aquaculture has made significant growth in Asian regions, no such study has been carried out to cataloguing of drugs, chemicals and formulations used in aquaculture, except some work done in Bangladesh [17-20]. However, in India, no appropriate research works have been carried out on the impact of aquaculture drugs and chemicals in fish health management and its impact on environment. There is also growing concern on potential misuse of some of these chemicals and health hazard. With this idea in mind the present investigation was aimed to provide some information on the uses of drugs, chemicals and formulations in various aquaculture practices including diseases management in aquaculture dominant and progressive states like Andhra Pradesh, Odisha, West Bengal, Jharkhand and Chhattisgarh.

\section{Materials and Methods}

Methodology: Questionnaire based survey was carried out in aquaculture dominant and progressive states like Andhra Pradesh, Odisha, Jharkhand and Chhattisgarh (Figure 3).

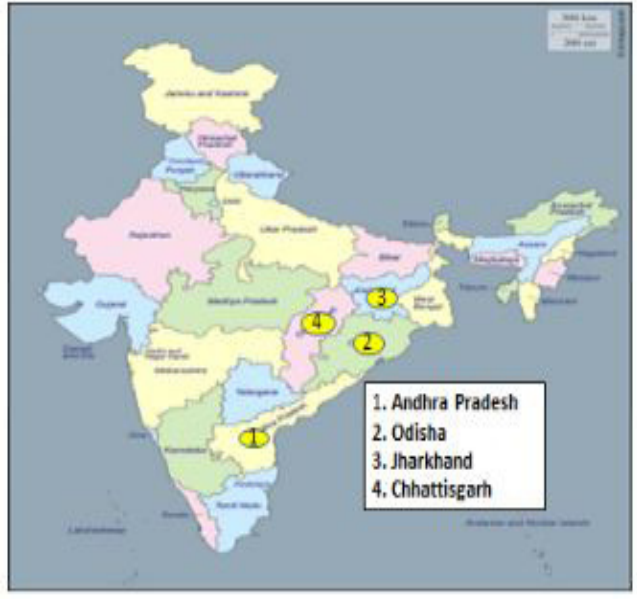

Figure 3: Showing survey areas where the present investigation was undertaken in India

Both primary and secondary data were used during the study. Primary data were collected through field surveys in different districts, to have on spot assessment at farmers field. Specific prescribed questionnaire "Survey on usage pattern of drugs and chemicals in Indian aquaculture under All India Network Project on Fish Health" was used for survey. Data were collected through interview and personal interaction with fish and shellfish farm owners, hatchery operators, drugs/ chemicals selling units, aquamedicine representative of various pharmaceuticals companies. Data on use of chemicals, active ingredients of aqua-medicines, their indications, method of application in field, dose, effectiveness, duration of application, cost and effect on environment were collected as per the format. Detailed information was also collected from State Government Fishery Departments of Andhra Pradesh, Odisha, Jharkhand and Chhattisgarh states. Secondary source of information consisted of published reports, training material, newsletters of fish and shrimp production companies, nongovernment organizations, appropriate government organizations like Marine Products Export Development Authority (MPEDA), Coastal Aquaculture Authority (CAA) etc. The data were analyzed using tabular and descriptive statistical techniques.

\section{Results and Discussions}

Fish and shrimp Aquaculture has made significant growth in coastal states of India, like in Andhra Pradesh (A.P), Odisha, West Bengal (W.B) Karnataka, Tamil Nadu and Kerala, while carp culture has progressively developed in Inland states like in 


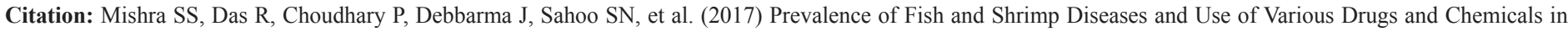
Indian Aquaculture for Disease Management. J Fish Aqua Dev: JFAD-129. DOI: 10.29011/JFAD-129. 100029

Jharkhand, Chhattisgarh, Punjab and Haryana. In Andhra Pradesh, pond culture was initiated in the Kolleru lake region and spread to the surrounding districts of West Godavari and Krishna, which are currently the center of Indian major carp culture. Fish and shrimp production data indicates Andhra Pradesh produced 414349 Metric Ton (MT) of Marine and 1393728 MT of inland fish with total production of 1808077 MT of fish which was the highest in India. Similarly, Odisha produced 118311 MT of marine and 291832 MT of inland fisheries with total of 410143 MT fish. However, both Chhattisgarh and Jharkhand being inland states produced only freshwater fish amounting 255611 MT and 96600 MT fish, respectively, and the fish production potential is being enhanced every year [8]. As such Andhra Pradesh has been the center of modern aquaculture with all innovative and scientific practices with intensive culture have been taken up in this zone and the activities are spreading to neighboring states like in Odisha. Nonetheless this state supplies fish to all over the country and even exporting to the neighboring countries. In recent years, tremendous progress in carp and shrimp culture has also been made in Odisha, while carp aquaculture has become prominent in Chhattisgarh and Jharkhand states, especially in cage culture in reservoirs and wetlands. Hence these four states were chosen to survey of aquaculture activities including disease problems faced by the farmers and use of various drugs and chemical in aquaculture. Both freshwater fish species and brackish water shrimp culture ponds were surveyed. It was observed that the freshwater aquaculture comprises of the culture of mainly three species of Indian major carps (IMC) viz. Catla catla (Catla), Labeo rohita (Rohu), and Cirrhinus mrigala (Mrigal) which constitute between $70 \%$ and $75 \%$ of the total freshwater fish production, with maximum emphasis on Labeo rohita production. In some farms three exotic species Hypophthalmichthys molitrix
(Silver carp), Ctenopharyngodon idella (Grass carp) and Cyprinus carpio (Common carp) are being cultured along with IMCs. Genetically improved Tilapia (Oreochromis mosambicus and Oreochromis niloticus) and Pangasius (Pangasiandon hypophthalamus) have gained popularity in some zones. Another exotic fish called Pacu (Piaractus brachypomus) which has accessed to Indian aquaculture through illegal route, has gained popularity in this zone, for its high growth potential, even in low saline pond culture systems, with less occurrence of disease problems and appreciable meat quality. The fish produced in Indian freshwater aquaculture system are mostly consumed in domestic market because of high consumer demand and low market value at international market, nonetheless, some are also exported to neighbouring Asian countries. Culture of brackish water species like indigenous shrimp Penaeus indicus, Tiger shrimp (Penaeus monodon) and exotic white leg shrimp (Penaeus vannamei) are commonly practised in the region, which is mostly export oriented, considering high international value of the species cultured and demand at International market.

In most of the fish farms, it was observed that among all fish pathogens, parasitic infestation has been the major cause of concern because of high morbidity and slow growth rate. These parasites were difficult to be removed from the culture system, causing significant setback to freshwater aquaculture. Under poor water quality conditions or stressful environment, these parasites multiply rapidly there by affecting fishes with high morbidity. Fish parasites, mostly, the protozoan ciliates (Ichthyophthirius sp., Trichodina sp.), monogenetic trematodes (Dactylogyrus sp., Gyrodactylus sp.) and larger crustacean ectoparasites viz. Lernae spp., Argulus spp., Ergasilus, were commonly reported from cases of fish diseases (Table 1).

\begin{tabular}{|c|c|c|c|}
\hline S. NO & Bacterial Diseases & Parasitic Diseases & Fungal \& Viral diseases \\
\hline 1 & Red disease & Argulosis & Saprolegniasis \\
\hline 2 & $\begin{array}{c}\text { Motile Aeromoniasis or ulcerative } \\
\text { disease }\end{array}$ & Dactylogyrusis (Gill fluke) & Ichthyophornasis \\
\hline 3 & Bacterial gill disease & Gyrodactylosis (Skin fluke) & disease) \\
\hline 4 & Fin rot and Gill rot disease & $\begin{array}{c}\text { Ichthyophthiriasis (White spot } \\
\text { (EUS) }\end{array}$ & $\begin{array}{c}\text { Epizootic Ulcerative Syndrome } \\
\text { Trichodiniasis }\end{array}$ \\
\hline 5 & Infectious Dropsy & Ergasilosis & Viral Diseases \\
\hline 6 & Eye disease & Tilapia Lake Virus (suspected) \\
\hline 9 & Columnaris disease & & \\
\hline
\end{tabular}

Table 1: Common bacterial, fungal and parasitic diseases recorded from cultured freshwater fish in pond culture system.

Unlike in fish culture, parasitic infestations were found not to be a major problem in shrimp culture, although some cases of parasitic infestations were reported (Table 2). 


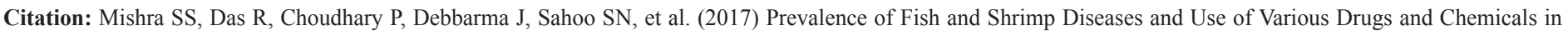
Indian Aquaculture for Disease Management. J Fish Aqua Dev: JFAD-129. DOI: 10.29011/JFAD-129. 100029

\begin{tabular}{|c|c|}
\hline Diseases & Causative agent \\
\hline \multicolumn{2}{|l|}{ A. Bacterial diseases of Shrimp } \\
\hline Necrosis of appendages & Vibrio spp., Pseudomonas sp., Aeromonas sp., and Flavobacterium sp. \\
\hline Vibriosis & Vibrio alginolyticus, $V$. parahaemolyticus, $V$. anguillarum \\
\hline Luminescent bacterial disease & V. harveyi \\
\hline Filamentous bacterial disease & Leucothrix mucor \\
\hline Brown spot disease (Shell disease or Rust disease) & Vibrio sp., Aeromonas sp., Flavobacterium sp. \\
\hline Bacterial septicaemia & Vibrio sp. \\
\hline $\begin{array}{l}\text { Acute Hepatopancreatic Necrosis Disease / Early Mortality Syndrome } \\
\text { (AHPND/EMS), }\end{array}$ & Bacteria: Vibrio parahaemolyticus and other Vibrio species \\
\hline \multicolumn{2}{|l|}{ Viral diseases of shrimp } \\
\hline Monodon Baculoviral (MBV) disease & $\begin{array}{c}\text { Monodon Baculo virus (MBV), } \\
\text { dsDNA, size, } 75 \times 300 \mathrm{~nm} \text {, Baculovirus, occluded }\end{array}$ \\
\hline White spot disease & $\begin{array}{c}\text { White spot Syndrome Virus (WSSV), } \\
\text { Baculovirus, dsDNA, Family: Nimaviridae, } \\
\text { Genus: Whispoviru }\end{array}$ \\
\hline $\begin{array}{c}\text { Infectious Hypodermal and Hematopoietic Necrosis Virus (IHHNV) } \\
\text { disease }\end{array}$ & $\begin{array}{c}\text { IHHNV, single stranded, small and non-enveloped DNA virus, } \\
\text { Parvovirus, family: Parvoviridae }\end{array}$ \\
\hline Hepatopancreatic Parvovirus (HPV) disease & $\begin{array}{l}\text { HPV, ssDNA virus, Parvovirus } \\
\text { family: Parvoviridae }\end{array}$ \\
\hline Infectious Myonecrosis virus (IMNV) disease & $\begin{array}{l}\text { Infectious Myonecrosis virus (IMNV), Size: } \sim 40 \mathrm{~nm} \text {, un-enveloped, } \\
\text { dsRNA, Family: Totiviridae }\end{array}$ \\
\hline \multicolumn{2}{|l|}{ Fungal Diseases } \\
\hline Protozoan fouling & Protopzoans: Vorticella, Zoothamnium, Epistylis, Acineta and Ephelota \\
\hline Larval mycosis & $\begin{array}{l}\text { Oomycetous fungi such as Lagenidium sp., Sirolpidium sp., } \\
\text { Haliphthorous sp. }\end{array}$ \\
\hline \multicolumn{2}{|l|}{ C. Parasitic diseases of shrimp } \\
\hline Cotton shrimp disease & Microsporidia: Agmosoma, Ameson and Pleistophora \\
\hline Bopyrid parasitic infestation & Bopyrid parasite, Epipenaeon sp. \\
\hline Enterozoic Cephalin gregarine infection & Protozoan: Cephalolobus sp. \\
\hline Hepatopancreatic microsporidiosis (HPM) & Enterocytozoon hepatopenaei (EHP), microsporidian parasite \\
\hline \multicolumn{2}{|l|}{ D. Environmental diseases of shrimp } \\
\hline Chronic soft-shell syndrome & Environmental factors such as $\mathrm{pH}$, salinity, temperature, organic matter \\
\hline Black gill disease & Environmental as well as microbial agents \\
\hline Cramped tail disease & Not Known \\
\hline White gut disease & \\
\hline
\end{tabular}

Table 2: Occurrence of some bacterial, viral fungal and parasitic diseases recorded in cultured shrimps in India.

In some areas in Andhra Pradesh, occurrence of a new parasitic disease called Hepatopancreatic Microsporidiosis (HPM) caused by Enterocytozoon hepatopenaei (EHP), a microsporidian parasite was reported and during October 2015, India's Marine Products Export Development Authority (MPEDA) gave warnings about the spread of EHP in India's shrimp farms [21]. Low level prevalence of EHP associated with "Slow growth syndrome" in tiger shrimp was observed [22]. However, in the present investigation, not much mortality due to parasitic infestations in shrimp could be recorded in four states where survey was carried out. However, parasitic infestations causing high morbidity and production loss was recorded in most freshwater fish farms employing carp culture. Among all parasites infestation with Orgulous was maximum followed by Dactylograms sp. affecting gills. Occurrence of Myxobolous, Trichodina and Ergasilus sp. were also reported but with less number of incidences, as reported previously [10,23,24]. In the present survey it was 


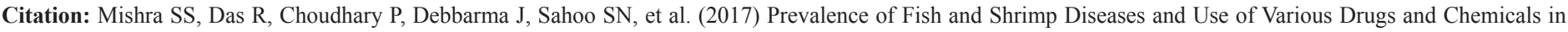
Indian Aquaculture for Disease Management. J Fish Aqua Dev: JFAD-129. DOI: 10.29011/JFAD-129. 100029

observed a variety of drugs and chemicals were used in fish and shrimp culture for disease management and control. It has been reported that various aquaculture drugs have wide application in health management, pond construction, soil and water quality improvement, productivity enhancement, feed formulation, manipulation of reproduction, growth promotion and processing and value addition of the final product $[14,20]$. As reported earlier, most of the aqua-medicine, drugs and chemicals commercially available in the market could be categorized in to six types, i) Those chemicals and formulations for water quality management in cultured ponds, ii) Anti-parasitic drugs and chemicals iii) Disinfectants and sanitizers iv) Probiotics and water remediation products v) Feed Supplements and growth promoters and vi) Antibiotics [25]. It was observed that in fish culture, parasitic infestations were major cause of concern flowed by alteration in water quality and bacterial disease. Single or multiple parasites were involved alone or along with bacterial infections causing severe damage to host tissues [10]. Fish parasites interfere with nutrition of hosts, disrupts metabolism and secretary functions of alimentary canal and damage nervous system [26,27], thereby reducing growth rate and even mortality, which result in substantial economic loss in fish culture system in India. Hence farmers in the region use anti-parasitic drugs, chemicals, organic products, even various pesticides and insecticides to control fish parasitic infestations, as presented in (Table 3).

\begin{tabular}{|c|c|}
\hline Anti-Parasitic Drugs & Antiseptics \& Disinfectants \\
\hline Bancoxy-K (Amprolium hydrochloride 20\% & Bactovirnil: (Potassium Monopersulphate and Sodium Dodecyl benzene Sullphonate) \\
\hline ButoxVet (Deltamethrin 1.25\%) & Bionex-80: (Alkyl Dimethyl Benzyl Ammonium chloride 80\%) \\
\hline BROFIN $^{\mathrm{TM}} 5 \%$, (Bromine 5\%) & Benzalkonium Chloride (50\%) \\
\hline Clinar (Cypermethrin) & Blesson (Benzalkonium Chloride) \\
\hline DICHLORVOS-E.C. 76\%, (Dichlorvos-76\%) & $\begin{array}{c}\text { Broot 5X: (Tetradecyletrimethyle Ammonium Bromide, Alkylbenzyledimethyle ammonium } \\
\text { chloride) }\end{array}$ \\
\hline Decis (Deltamethrin 2.8\%) & $\begin{array}{c}\text { Biolin plus: (Formaldehyde, Strong Glutaraldehyde, } \\
\text { Benzalkonium Chloride) }\end{array}$ \\
\hline ECTO DEL 2.8\%, (Deltamethrin 2.8\%) & BKC PLUS:(Dimethyl Benzyle ammonium chloride \\
\hline HILMALA (Malathion Tech. 52.8\%) & ECODYNE: (Polyvinyl Pyrolidone Iodine20\%) \\
\hline HITEK Powder (Ivermectin IP 1\% w/w) & GERMICIDA: (Sodium chloride, Potassium onopersulphate) \\
\hline NIVaar (Azadiractin 0.15\%) & Glyphogan: (Glyphosate 41\%) \\
\hline NUVAN (Dichlorvus Tech. 83.0\%) & Formal Dehyde solution-37-41\% w/v \\
\hline PARAMED (Amprolium hydrochloride 20\%) & Malachite green \\
\hline PARACURE - I.V (Ivermectin: 2\%) & MIZUPHOR: (Alkyl aryl polyoxyethylene iodine complex) \\
\hline STARCHLOR (Dichlorovus-76\% .) & NOVIR: (Potassium- peroxomonosulphate, Sodiumdodecyle-benzenesulphate, Sulphamic acid) \\
\hline Common Antibiotics & POLGARD + (3 methyl, 4 alkyl 2 chain brominated halogen compound) \\
\hline CEFINTAS AQ (Cephalexin) & PROTECT (Alkyl dimethyl Benzal Ammonium chloride 50\% w/v) \\
\hline Enrox (Fluoroqunolone) & Potassium Permanganate \\
\hline Hydrodox (Doxycycline) & Sokrena-WS (Didecyledimethyle ammonium chloride) \\
\hline Lixen Powder (cephalexin) & STERIDOL P.F. (Nonyle alkyl phenoxy Choline, Ethelene oxide Iodine) \\
\hline Oxymycin (Oxytetracycline HCL) & Viranil (Potassium Monopersulfate, Potassium sulphate, Potassium hydrogen sulphate) \\
\hline Oxytetracycline Soluble I.P (Vet.) & Vir GO (Potassium monopersulphate $50 \% \mathrm{w} / \mathrm{w}$ ) \\
\hline
\end{tabular}

Table 3: Different Anti-parasitic drugs, chemicals formulations and antibiotics commonly used in aquaculture* (Adopted with modification from 


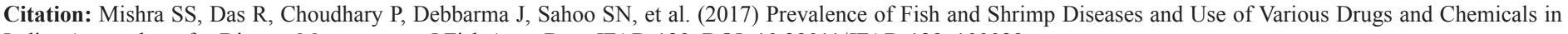
Indian Aquaculture for Disease Management. J Fish Aqua Dev: JFAD-129. DOI: 10.29011/JFAD-129. 100029

(Mishra et al., 2017b) [25].

As such, so far, no anti-parasitic drugs nor insecticides have been permitted for use in fish culture in India, but farmers are in habit of using such preparations as used in animal health care (veterinary medicines) or in agriculture (Insecticides and pesticides). These drugs included Paramed, Nuvan, Decis, Himalaya, Starchlor, Butox vet, Cliner, Ectodel (2.8\%), Emamectin Benzoate, Hitek Powder, Paracure-IV, Dichlorovos (Table 3) [17,25,28] reported use of Melathion and Sumithion (Fanitrothion) [20] in most fish farms in Bangladesh, for control and eradication of external parasites as well as fungal diseases. Use of Malathion in any practice has been banned in India, but some farmers are illegally using it in fish ponds to get rid of unwanted fish and parasites, there by polluting the environment. In European countries the antiparasitic drugs that are mostly used to control the sea lice, contains dichlorvos, azamethiphos, hydrogen peroxide, ivermectin, emamectin, cypermethrin, deltamethrin, teflubenzuron, and diflubenzuron as the active ingredients [29]. Although a number of products appear to be available to veterinarians and salmon farmers in European countries only a few are prescribed. Only Emamectin Benzoate (EB), is used as medicated feed in all jurisdictions. In fact, this is the only product used in Canada (under Emergency Drug Release) and the US (INAD) [30] for control of parasitic infestations in fish. It was also observed change in attitude of some fish farmers in Andhra Pradesh to use organic products like containing neem (Azadirachta indica) extracts or neem oil to control fish parasitic infestations. Experimental trial by some farmers have shown encouraging results and occurrence of Argulosis was not reported in the fish farm since last three years. Again, some farmers use farm made fermented extract locally called as "Jivamrutam" which contain cow urine, cow dung, molasses, rice bran and sometimes Black gram (Vigna mungo). After nearly 5-6 days of fermentation, the fermented product is applied. As per their view, application of the product was very useful in protecting the fish from parasitic infestations and enhancing plankton production. However, its efficacy in shrimp ponds have not been evaluated. Such type of innovative trials by fish farmers in Andhra Pradesh are appreciated by farmers and scientific community and more awareness programme are needed to spread the message.

Besides parasitic infestations, a wide variety of bacterial disease like motile aeromonads septicaemia, Edwadsiellosis, Pseudomonas septicaemia, Flexibacteriosis, bacterial gill disease, streptococcal septicaemia, mycbacteriosis, columnaris disease etc. were recorded in various semi-intensive or intensive fish culture ponds. However, motile aeromonad septicaemia locally called as red disease, was considered to be the most common and troublesome among all bacterial diseases [23]. Bacterial diseases were frequently encountered in eggs, fry, fingerlings of fish, causing heavy mortality. Similarly, in shrimp culture, $P$. vannamei has been extensively cultured both in freshwater and saline waters in Andhra Pradesh, while in Odisha, culture of tiger shrimp P. monodon, local species $P$. indicus and exotic shrimp $P$. vannamei are being cultured in monoculture by most farmers. In Chhattisgarh and Jharkhand, $P$. monodon is predominantly cultured. Occurrence of different bacterial diseases or mixed infections with fungal pathogens in shrimp culture were observed in these states, which included Luminescent bacterial disease, Vibriosis, Bacterial septicaemia and larval mycosis These microorganisms are essentially opportunistic pathogens which invade the tissues of a fish host rendered susceptible to infection by stress factors [31]. Hence, poor or abnormal water quality is a predisposing factor making the cultured fish susceptible to bacterial opportunistic pathogens. Contrary to number of bacterial and parasitic diseases, only a few number of fungal diseases were reported in fish culture. Most fungal infections recorded from fish were those caused by species belonging to the oomycete fungi, Saprolegnia, Achlya and Aphanomyces. Diseases caused by these fungi are collectively called "Saprolegniasis" [32,34]. Another important fungal induced disease in fish culture of high economic importance observed was Epizootic Ulcerative Syndrome (EUS). It is an important bacterial-fungal disease responsible high mortality in freshwater fishes [10]. However, the incidences of EUS has been drastically reduced compared to that reported a decade ago [32]. In most shrimp culture ponds occurrence of Protozoan fouling caused by Zoothamnium, Epistylis etc. and Larval mycosis caused by Oomycetes fungi such as Lagenidium sp., Sirolpidium sp., Haliphthorous sp. were reported (Table 2). Mostly fungi are present in water and under unfavourable conditions, they attack the animals causing skin lesions and cloaking the gills of shrimp, often causing production loss.

Besides common bacterial diseases other emerging diseases have also reported in Andhra Pradesh. Acute Hepatopancreatic Necrosis Disease (AHPND) also commonly called Early Mortality Syndrome (EMS) has been currently the most important non-viral disease threat for cultured shrimp $P$. vavvamei. It is usually characterized by mass mortality during the first 35 days of culture. This disease is caused by certain strains of ubiquitous in marine and brackish water bacteria called Vibrio parahaemolyticus $[2,35]$. In India, EMS in $P$. vennamei culture was reported in Andhra Pradesh and Tamil Nadu during 2015-16, which caused significant production loss in $P$. vennamei culture. Affected farms suffered continuous low-level mortalities, low survival and reduced productions $[35,36]$. Besides occurrence of bacterial diseases, outbreaks of White Spot Disease (WSD) caused by White Spot Syndrome Virus (WSSV), Black Gill Disease (BGD), Running Mortality Syndrome (RMS), Loose Shell Syndrome (LSS), White Faecal Syndrome (WFS), Infectious Hypodermal and Haematopoietic Necrosis (IHHN), Stunted growth disease, Microsporidiosis and Zoea syndrome, in shrimps causing economic loss to the aquaculture in Andhra Pradesh have been reported [36]. Some farmers reported loss up to 60 per cent of their investment due to these diseases. $P$. vennamei are both in freshwater and saline waters and the viral outbreaks in $P$. vannamei were shown to be minimal in low saline waters compared to the high saline waters (Srinivas et al., 2016) [36]. In the present survey, different shrimp farms were seen to be affected with various bacterial induce shell necrosis disease, AHPND / EMS disease, WSD, RMS, LSS and WFS. 


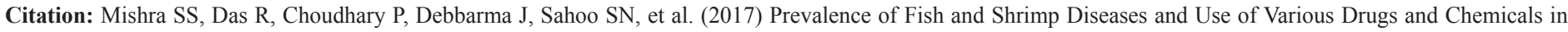
Indian Aquaculture for Disease Management. J Fish Aqua Dev: JFAD-129. DOI: 10.29011/JFAD-129. 100029

To control diseases problems, farmers were seen to use various anti-bacterial, anti-fungal agents and disinfectants both in fish and shrimp ponds and hatcheries. These were also used in site and equipment preparation, to maintain hygiene throughout the production cycle. Some chemicals which were commonly used for disinfection of the pond environment includes Bankonxy-k, Blue Caloxy, VirGo, Germicida, Ecodyne, Viranil, Mizuphore, Bionex-80, Sokrena-WS, Methylene blue, formalin, hydrogen peroxide, potassium permanganate, copper sulphate, malachite green, Bleaching, Aquakleen, BKC (Benzalkonium chloride), BKC Plus, Biolin Plus, Steridol P.F., PROTECT, Batovirnil, Efinol, Novir, POLGARD, Glyphogan etc. as reported earlier (Mishra, 2017b). Formalin was also used to control protozoan disease. BKC-50 (Benzalkonium chloride) was commonly used for controlling bacterial disease. Use of such types of chemicals in Bangladesh aquaculture has also been reported by various authors [17,28,37]. Some of these chemicals are shown to have adverse impact. Formalin, has been approved by the US FDA for use in aquaculture, but when applied to ponds, can kill phytoplankton and cause oxygen depletion. Similarly, Formalin apparently reacts with ammonia to form hexamethylenetriamine and possibly formamide, a toxic substance to aquatic ecosystem. These chemicals are used mostly in hatcheries and, to a limited extent, in grow-out ponds [13]. In Bangladesh, fish farmers use a variety of chemicals in the treatment of disease as preventive or control measure which included chemical preparations like Aquakleen, BKC, bleaching, EDTA, efinol, formalin, water clear, omicide [17,37], reported use of lime, urea and TSP were the mostly used. Bleaching powder, Timsen, EDTA, Polgard, Virex, Aquakleen, Germnill, Pond safe were widely used as disinfectant and water quality management in Bangladesh aquaculture [37].

Although there are more than 125 different viruses in fish culture around the globe including many Asian countries [2,38,39], Indian fishery sector has been fortunate in this regard that that no major occurrence of viral diseases has been reported in carp culture. In our survey in four states, not a single case of viral disease outbreaks in fish culture could be recorded. Earlier there were some reports of occurrence viral diseases like Viral Nervous Necrosis (VNN) or Fish Noda virus affecting brackish water food-fish Lates calcarifer larvae only for a limited period without much economical loss to sector in India [40,41]. Recently, it was observed that some farmers were worried about incidences of Tilapia Lake Virus (TiLV), affecting farmed tilapia (Oreochromis niloticus) and other Tilapia (Oreochromis spp.) in the Asia-Pacific Region in India, although there are some reports of tilapia kills in some ponds, suspected to be TiLV, it has not yet been confirmed [42]. Hence (Marine Products Exports Development Authority (MPEDA) have warned the aqua farmers about probable invasion of TiLV to aquaculture sector in India, so as to take suitable preventive measures to prevent production loss. Alert has been issued to aqua farmers on the spread of dreaded Lake Virus, in Tilapia fish in India. The Indian Council of Agricultural Research (ICAR) has sounded a caution to farmers on the outbreak of the virus in India [36].

Contrary to fish culture, shrimp aquaculture has not been so lucky as viral diseases have been a major problem in the shrimp aquaculture industry worldwide. Serious viral outbreaks often cause catastrophic losses in shrimp farming around the globe [43]. Since 1981, a succession of new viral pathogens has emerged in Asia and the Americas, causing mass mortalities and threatening the economic sustainability of the industry [11]. Shrimp are arthropods and most shrimp viruses are either related to those previously known to infect insects (e.g., densoviruses, dicistroviruses, baculoviruses, nodaviruses, luteoviruses) or are completely new to science and have been assigned to new taxa [11]. In India, occurrence of Penaeu

s Monodon-Type Baculovirus (MBV) outbreak was reported from 1994-1999, causing serious mortalities within populations of cultured giant tiger prawn, Penaeus monodon (Fabricious) and Indian white shrimp, Penaeus indicus, leading to severe economic losses and virtual collapse of prawn farming in maritime states in India $[44,45]$.

This was followed by occurrence of Yellow Head Disease (YHD) caused by Yellow Head Virus (YHV) in Andhra Pradesh during $1994[45,46]$. Mass mortality up to $100 \%$ was reported within 3-4 days on onset of disease. However, YHD subsided subsequently and no further occurrence of YHD was recorded in India. The most striking emerging disease in shrimp farming which has caused serious havoc in aquaculture industry around the globe is White Spot Disease (WSD), caused by White Spot Syndrome Virus (WSSV). The disease was reported in Andhra Pradesh during 1994 and continued for many years. Within a short span of time, the disease became pandemic and the farmers suffered huge loss as most of the farms were virtually wiped out because of this disease [44]. The virus affected most cultured shrimp species including $P$. monodon, $P$. indicus, $P$. vennamei and Macrobrachium resenbergii. The WSSV has been considered as a serious threat to prawn culture because it infects a wide spectrum of crustaceans like crabs, lobsters and shrimp, some of which act as potent carriers [47]. In our survey we observed that WSD caused by WSSV was persisting as a low-level infection in most shrimp farms with variable output. While some $P$. vennamei farms completely lost cultured shrimp, some farmers even harvested good crop in spite of WSD infection. However, there was a fear in the minds of farmers of consequences of WSSV epidemic, so they take all sorts of preventive control measures in terms of application of various chemicals, antibacterial and even antibiotics, as advised by the local consultants (Figure 4 and 5). 


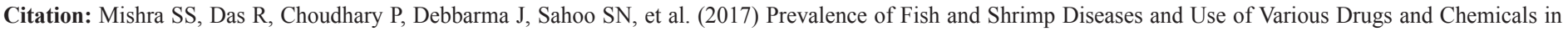
Indian Aquaculture for Disease Management. J Fish Aqua Dev: JFAD-129. DOI: 10.29011/JFAD-129. 100029

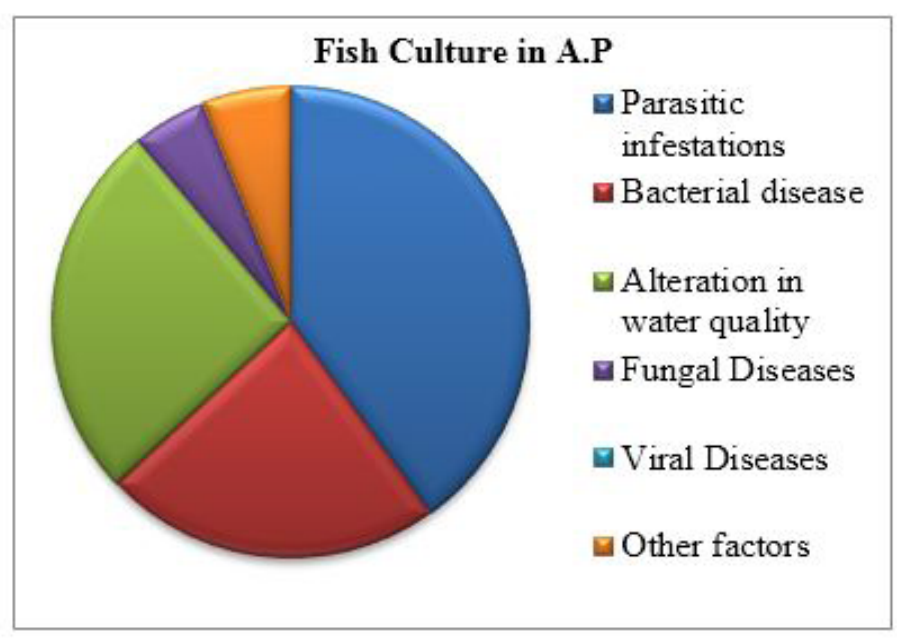

Figure 4: Showing prevalence of various disease problems in fish culture in Andhra Pradesh (A.P).

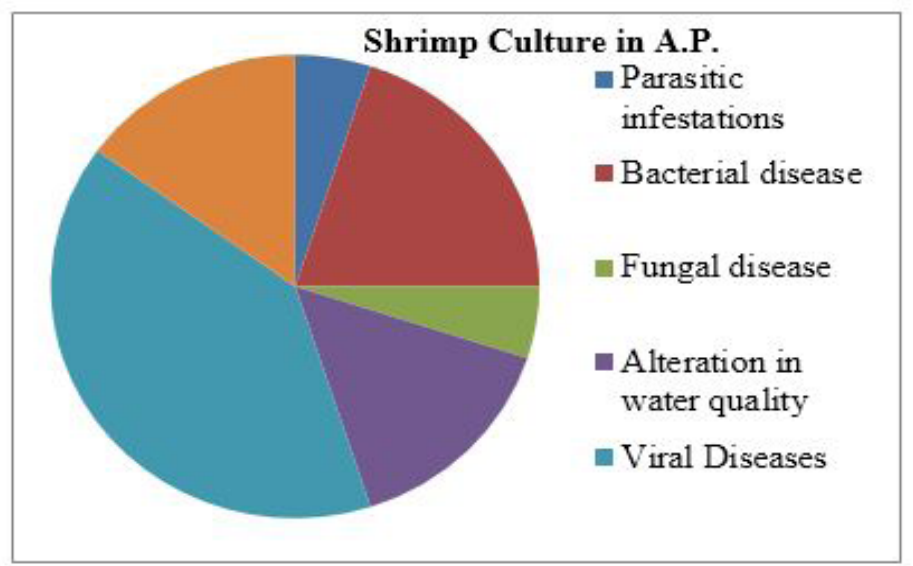

Figure 5: Showing prevalence of various disease problems in Shrimp aquaculture in Andhra Pradesh (A.P).

The disease pattern was variable in different states. In Andhra Pradesh, it was observed that cases of parasitic infestations in freshwater fish culture was the maximum (40\%). This was followed by loss due to alternation in water quality parameters $(26 \%)$ leading to production loss. Infection of fish with bacterial pathogens were in the range of $23 \%$, fungal diseases in $5 \%$ cases and in only $6 \%$ cases the mortality are due to other factors, similar to that reported earlier [23]. However, in Odisha, cases of parasitic infestation and bacterial diseases were almost equal proportions. Usually, deterioration of water quality often led to occurrence of bacterial or parasitic infestation. Some cases (10-12\%) of mortality were reported due to oxygen depletion, normally during winter periods. In both Chhattisgarh and Jharkhand disease problems were minimal compared to other states. Some occurrence of bacterial red disease and parasitic infestations were reported. However, in cage culture, disease occurrence, morbidity and mortality were very high, because of high stocking density that favours disease transmission among the group. Cases of bacterial induced red disease, ulcerative disease and fungal diseases were commonly reported. Tail rot and Fin rot were common and fungal diseases like Saprolegniasis, also called "Cotton wool disease" caused by Saprolegnia parasitica and Achyla species were commonly reported during winter months, when the cage nets are clogged with fouling agents [48]. However, no cases of viral disease either in carps or tilapia were noticed during the survey period. Another significant observation was seasonal variation in occurrence and severity of fish diseases in freshwater aquaculture. Whereas incidences of red disease or Motile Aeromoniasis were common during all seasons, the incidences of Black-gill disease were more during winter periods. Among parasitic diseases, occurrence of Argulousis and Gill fluke disease were comparatively more during winter and postrainy season. Hence, the farmers were advised to take due preventive and control measures during post-rain and winter seasons in grow-out culture system [23]. However, in shrimp P. vennamei culture in Andhra Pradesh, the disease prevalence scene was observed to be different. Most cases of disease (35-40\%) were White Spot Disease (WSD) and Running mortality syndrome of viral origin. This was followed by $10-20 \%$ cases of bacterial induced shell necrosis, and EMS/ AHNPD, as reported by the farmers. Some non-specific factors induced diseases (15-20\%) like Loose Shell Syndrome (LSS) and White Gut Disease (WGD) or White Fecal Disease (WFS). Water quality like depletion of DO was the major problem in $10-15 \%$ cases but was critical factor in most of the farms. Occurrence of parasitic and fungal diseases were minimal (4-8\%), as most shrimp farms maintained good water quality.

It was observed that antibiotics with different trade names were available in the market as well as used by the fish farmers as preventive and control measures. Among antibiotics, Oxymycin, Enrox, Lexin Powder, Hydrodox, Oxytetracycline, Cefintas AQ were commonly use in aquaculture [25]. In Bangladesh, [37] reported that the antibiotic, renamycin (oxytetracycline) had significantly controlled the bacterial infection when used at a dose rate of $50 \mathrm{mg} / \mathrm{Kg}$ body wt/day for 3-5 days with $80-90 \%$ efficacy. Ali et al., (2014) [17] reported use of various antibiotics like Acimox (vet) Powder, Bactitab, Chlorsteclin, Cotrim-Vet, Fish cure, Orgacycline-15\%, Otetra vet power 50, Oxin WS, Oxysentin 20\%, Ranamox, Renamycin and Sulfatrim in Bangadesh aquaculture. The active ingredients of such antibiotics were mainly Oxytetracycline, Chloro-tetracyclin, Amoxicillin, Co-trimoxa zole, Sulphadiazine and Sulphamethoxazole [17]. found oxytetracycline, Sulfadiazine and Trimethoprim combination antibiotics as popular chemotherapeutants in freshwater aquaculture and hatchery systems in India.

Although the etiological factors for White Fecal Disease (WFS) or White Gut Disease (WGD) in shrimp is not fully understood, some farmers in Andhra Pradesh adopted an innovative method of using traditional medicines containing a mixture of Tamrind (Tamarindus indica), garlic (Allium sativum), dried ginger (Zingiber officinale) fermented Palm oil (Elaeis guineensis). 


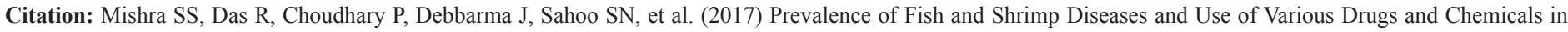
Indian Aquaculture for Disease Management. J Fish Aqua Dev: JFAD-129. DOI: 10.29011/JFAD-129. 100029

Although scientifically not proved, the application of this mixture two times a day with feed for 4-5 days was reported to cure the shrimp (P. vennamei) from MGD.

Sharker et al., (2014) [28] reported for protection against bacterial disease, farmers in Bangladesh were in habit of using various antibiotics and antimicrobials in aquaculture like Renamycin, Bactitab, Chlorsteclin, Cotrim-Vet, Orgacycline-15\%, Oxysentin $20 \%$ and Sulfatrim. Oxysentin 20\% and Orgacycline-15\% were effective against EUS, while Chlorsteclin was effective against dropsy, tail and fin rot, gill rot of fish etc. The active ingredients of such antibiotics were mainly Oxytetracycline, Chloro-tetracyclin, Amoxicillin, Co-trimoxa zole, Sulphadiazine and Sulphamethoxazole [28,37], reported that in Bangladesh, health management and disease treatment were the major activities where farmers were seen to use a lot of chemicals. A range of chemicals including antibiotics were found available in market and being used in the aquaculture sector. Commonly found traditional chemicals in heath management included Potassium permanganate, Lime, Salt, Virex, Timsen, Aquakleen, Germnil, Pond Safe, Deletrix, Spa, Albez, Ablez were used regularly for disease treatment. Mostly used antibiotics are Renamycin, Oxysentin 20\% Chlorsteclin Oxy-D Vet, Aquamycin, Orgamycin $15 \%$, Orgacycline-15\% etc. Major active ingredients of these antibiotics were oxytetracycline, chlorotetracycline, amoxicillin, doxycycline etc. Simiarly, Ali et al., (2014) [17] reported use of a wide variety of antibiotics like Acimox (vet) Powder, Bactitab, Chlorsteclin, Cotrim-Vet, Fish cure, Orgacycline- $15 \%$, Otetra vet power 50, Oxin WS, Oxysentin 20\%, Ranamox, Renamycin and Sulfatrim in Bangladesh aquaculture. There were approximately fifty-two pharmaceutical companies have been recorded to market around 300 products. Most of the products have been marketed from different countries like USA, Thailand, Malaysia, Belgium and China etc. [37].

Even though use of antibiotics in aquaculture practice is unwanted and harmful, these are being used for therapeutic and prophylactic and growth promoting purposes. Also, some manufactures are incorporating certain antibiotics in shrimp feed as a preservative. Even though antibiotics have no therapeutic value against viral diseases, still many farmers are using such antibiotic formulations in their farms against viral diseases [49], which has been a matter of abuse. It was observed that most farmers were unaware of the products and they were using the same as per the advice of some so called local fish health experts/ consultants and feed representatives. In shrimp hatchery operation at the Andhra Pradesh shrimp seed production, supply and research centre (TASPARC) hatchery at Bheemunipatnam, Andhra Pradesh, Calcium chloride, Sodium thiosulphate, EDTA were used as water treatment chemicals. Formalin, Idophore, potassium permanganate and dilute acids were used as disinfectants. Aquatic grade antibiotics like Chloramphenicol, Erythromycin, Oxytetracyclins, Furazolidone, kanamycin, neomycin and antifungal drugs like formalin, Treflan and malachite green were used in shrimp hatchery operations [50]. Antibacterial have been used mainly in juvenile or larval stages of aquatic animal production as prophylactic agents $[15,51,52]$. Among the antibiotics, oxytetracycline is one of the most widely used antibiotics in aquaculture practices throughout the world [37,53]. These antibiotics are used for treating the bacterial red disease or ulcer disease, bacterial hemorrhagic septicemia caused by A. liquefaciens, and Pseudomonas infections and Control of enteric septicemia of catfish caused by Edwardsiella ictaluristrains.

Besides infectious pathogens, non-infectious parameters like water quality plays a very important role in both fish and shrimp culture. It was reported that deterioration of water quality due to high stocking density, high organic load mostly due to accumulation of unused feed, less water exchange was the predisposing factor, making cultured animals prone microbial pathogens and parasitic infestations. In fish culture Low Dissolved Oxygen (DO) level especially during winter or cloudy weather and high ammonia level are other factors responsible for fish kills. It was also observed that that when total alkalinity value of pond water falls below the optimum range $(100-250 \mathrm{mg} / \mathrm{L})$ in grow-out ponds, fishes became more susceptible to microbial infections. Occurrence of red spots, skin ulcerative disease and fin rot were reported in such conditions. This required urgent attention, mainly to bring water total alkalinity level to optimum range by adding required quantity of lime $(\mathrm{CaO})$. Unless due care is taken at early stage, this may lead to occurrence of res-spots on skin, fins followed by secondary infections, leading to mass mortality. In shrimp culture farmers normally face three critical situations, which indicate survivability of standing crop, i) High level of pathogenic microbes due to high organic load, ii) high $\mathrm{NH}_{3}$ level and iii) low dissolved oxygen level. This led to farmers to use variety of chemical formulations and microbial probiotic preparations in the culture pond to reduce $\mathrm{H}_{2} \mathrm{~S}$, Ammonia and Nitrite level (Table 4). Various chemical formulations like Altimate ZM Aqua, Aqualite, Clinzex-DS, Halomex, Nutrisoft, Toxiclean Aqua, Ammo Trap, Ammon- Nil, BioCURB, De-Odorase, De-Odr, Mex Yucca, ODOCURE, Toxi Clean Aqua etc. (Table 4) were useful in reducing Ammonia, Nitrite and $\mathrm{H} 2 \mathrm{~S}$ level in shrimp culture ponds. However, different microbial based bioremediation products were available in the market and used mainly in shrimp culture ponds. These included Sulphanil-H, NOVIB, ThioMax, Optibact, PondDtox, TerraGardSP, Uni-Proclean, Clean bot, Eco Tech, Optima, pH FIXER, EcoToxonil, SludgeNil, BioClear etc. (Table 4). 


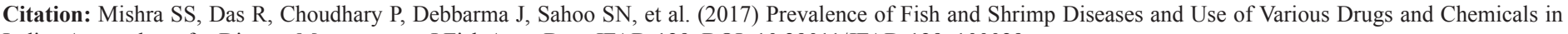
Indian Aquaculture for Disease Management. J Fish Aqua Dev: JFAD-129. DOI: 10.29011/JFAD-129. 100029

\begin{tabular}{|c|c|}
\hline Chemicals for Water Quality Management & Microbial Remediation Products \\
\hline $\begin{array}{l}\text { Addoxy (Tetraacetyl ethylene diamine, Sodium perborate, adsorbents } \\
\text { and de-odorizers) }\end{array}$ & $\begin{array}{c}\text { AMMO CURB: (Extract of the plant Yucca schidigera and fortified } \\
\text { with nitrifying bacteria (Probiotic). }\end{array}$ \\
\hline $\begin{array}{c}\text { ALTIMATE ZM AQUA } \\
\text { (Hydrated Sodium Calcium Alumino Silicates, buffered organic acids, } \\
\text { activated charcoal and dried neem leaf powder) }\end{array}$ & $\begin{array}{c}\text { BioClear: (Bacillus sp., Nitrobacter sp., Cellulomonas sp. and } \\
\text { Acetobacter) }\end{array}$ \\
\hline $\begin{array}{c}\text { AMMO-NIL+ } \\
\text { (Salts of alkyl sulfonic acids with saponins) }\end{array}$ & $\begin{array}{l}\text { Bio Balance }=\mathrm{C}: \mathrm{N}: \\
\text { Bacillus subtillis, Lactobacilus pentoues, Arthrobactor, Rhodococcus, } \\
\text { Nitrosomonas Nitrobactor, Thiobacillus, Bacillus liquifaecious }\end{array}$ \\
\hline Aqualite (Zeolite) & $\begin{array}{c}\text { BIOVET-YC: (Saccharomyces bolardii, Lactobacillus acidophilus, } \\
\text { Saccharomyces ceraevisiae) }\end{array}$ \\
\hline $\begin{array}{l}\text { Clarity (Edetic Acid, Hydrated alkaline sulphate, peroxides, Amitoxins, } \\
\text { Alluminium dehydrated silicates) }\end{array}$ & Bio-Trim: (Bacillus species) \\
\hline Clinzex-DS (Zeolite) & B4: (Bacillus species) \\
\hline Earth (Humic Acid, Humin Cytokynine, Auxine, Fuxine, Fulvic Acid) & $\begin{array}{c}\text { Clean Bot: (Aspergillus awamori, Daedaleaflavidaa, Trichoderma } \\
\text { reesei, Cellulomonas } \mathrm{spp} \\
\text { Pseudomonas } \mathrm{spp})\end{array}$ \\
\hline ENRICH (Ca, P, Fe, $\mathrm{Zn} \mathrm{Mg,} \mathrm{Cu} \mathrm{Co}, \mathrm{Cr}, \mathrm{Bo}, \mathrm{Al}$ as Chelating salts) & $\begin{array}{c}\text { Cura Mid: Nitrosomonas sp., Nitrobactersp., Bacillus sp., Aerobacter } \\
\text { sp., Cellulomonas sp }\end{array}$ \\
\hline $\begin{array}{l}\text { Halone (3 methyle,4Alkyl two chain brominated Halogen Compond- } \\
\qquad 6 \% \mathrm{w} / \mathrm{w} \text {, Potentiser) }\end{array}$ & $\begin{array}{c}\text { ECO TECH: (Bacillus subtillis; B.licheniforms B.meghatherium Ni- } \\
\text { trobactor, Nitrosomonas, Rhodococus) }\end{array}$ \\
\hline $\begin{array}{c}\text { Jinong Humic Acid } \\
\text { (Active Humic Acid, Nitrogen, Phosphorus, Potassium, Molybdenum } \\
\text { Manganese, Iron, Zinc, Boron, Copper) }\end{array}$ & ECO TOXNIL: Bacillus thermodenitrificans \& Bacillus sp \\
\hline MPC $\left(\mathrm{MgCl}_{2} \cdot 6 \mathrm{H}_{2} \mathrm{O}\right.$, Potassium chloride and sodium chloride fused $)$ & LACTO PLUS: (Lactobacillus \& Yeast culture) \\
\hline Modulox $^{\mathrm{TM}} \mathrm{Tab}$ (Sodium perborate) & $\begin{array}{c}\text { Nitrocare-LQ Yucca schidigera, Aloevera, Bacillus subtillus,Bacillus } \\
\text { polymyxin, Bacillus linchcniformis, Nitrosomonas, Nitrobacter, } \\
\text { Pseudomonas }\end{array}$ \\
\hline Nutrisoft (EDTA concentrated Aluminium dehydrated silicate) & NOVIB: (Bacillus amyloliquefaciens \& B cereus) \\
\hline $\mathrm{O}_{2}$ Marine (Sodium perborate) & $\begin{array}{c}\text { OptiBact: (Bacillus sutilis, circulans, megatherium, polymixa, } \\
\text { Thiobacilus, thiooxidans, denitrifians, Nitrosomans, Nitrobactor, } \\
\text { Rhodococcus and Rhodobacter }\end{array}$ \\
\hline $\mathrm{O}_{2} \mathrm{MAX}$ & $\begin{array}{c}\text { Optima: Bacillus subtills, Bacillus licheniformis, Bacillus megaterium, } \\
\text { Bacillus polyxa, Bacillus pumilus, Lactobacillus sporogenies, and } \\
\text { denitrifying bacteria }\end{array}$ \\
\hline Oxycal (Calcuim Peroxide) & $\begin{array}{c}\text { Pond Fresh: (Bacillus subtilis, B.licheniformis, B.Pumilus, Lactobacil- } \\
\text { lus lactis and Rhodobacter) }\end{array}$ \\
\hline
\end{tabular}




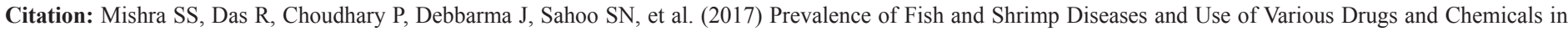
Indian Aquaculture for Disease Management. J Fish Aqua Dev: JFAD-129. DOI: 10.29011/JFAD-129. 100029

\begin{tabular}{|c|c|}
\hline Oxy-Gen (Calcuim Peroxide) & PondDtox: (Paracoccus pantotrophus) \\
\hline Sodium percarbonate tab & $\mathrm{P}^{\mathrm{H}}$ FIXER: (Bacillus species) \\
\hline TOXIMAR (natural zeolites) & $\begin{array}{c}\text { SACCHAROLACT: (Lactobacillus acidophilus, L. casei } \\
\text { L. buulgaricus, Streptococcus lactis } \\
\text { Bacillus subtillis, Saccharomyces cerevisiae) }\end{array}$ \\
\hline $\begin{array}{l}\text { Toxi Clean Aqua }\left(\mathrm{SiO}_{2}-51 \%, \mathrm{Al}_{2} \mathrm{O}_{3}-32 \%, \mathrm{Fe}_{2} \mathrm{O}_{3}-3 \%, \mathrm{Na}_{2} \mathrm{O}-3 \% \text {, }\right. \\
\qquad \mathrm{MgO}-2 \%)\end{array}$ & $\begin{array}{c}\text { SludgNil: Rhodococcus sp., Rhodobacter sp., Bacillus sp., Cellulomona } \\
\text { sp., Aspergillus sp., and Pseudomonas sp }\end{array}$ \\
\hline Organic Products for water quality management & $\begin{array}{l}\text { SULPHANIL-H: Thiobacillus, chlorobium, Disulfovibriodisulphuric } \\
\text { acid) }\end{array}$ \\
\hline Ammo Trap ( $10 \%$ of Glyco components from Yucca schidigera) & SuperBiotic: (Bacillus spp) \\
\hline BioCURB ${ }^{\circledR}$ Dry (Natural Extract of plant Yucca schidigera) & TerraGard-SP: (Thiobacillus and Bacillus species) \\
\hline De-Odorase (Ammonia Reducer: Yucca schidigera extract) & $\begin{array}{c}\text { ThioMax:(Bacillus subtillis, B. lichenformis, B.polymyxa, B. } \\
\text { megaterium, B. pumilus, B. spec (TF2), Nitrosomonas, Nitrobacter, } \\
\text { Thiobacillus spp) }\end{array}$ \\
\hline De-odr (Yucca schidigera and reducing agents with stabilizers) & THIOPRO-DS: Thiobacillus species, Nitrosomonas, Nitrobactor \\
\hline GARDIAN (Yucca schidigera plant extracts) & TOXOFF: B subtilis, Lactobacillus lacyis and Thiobacillus versutus \\
\hline MEX YUCCA (pure Yucca schidigera) & \\
\hline ODOBAN-A30 (Yucca schidigera steroidal saponins) & $\begin{array}{l}\text { UNI-PROCLEAN: Bacillus subtilis, B licheniformis, B megatherium, } \\
\text { B. Polymixa, B firmis, B mesentricus, Cellulomonascartae, } \\
\text { Pediococcus, Aspergillusoryzae, Perococcusdenitrifican }\end{array}$ \\
\hline ODOCURE (Yucca schidigera extract) & Y-MAX: (Saccharomyces cerevisiae, Saccharomyces boulardil) \\
\hline Toxi-Clean Aqua (Zeolite with YUCCA extract) & Yea Sacc: (Saccharomyces cerevisiae) \\
\hline \multicolumn{2}{|c|}{${ }^{*}$ Brand names with active ingredients mentioned in bracket } \\
\hline
\end{tabular}

Table 4: Chemicals, Organic materials and Microbial remediation products commonly used for water quality maintenance in Aquaculture* (Adopted with modification from (Mishra et al., 2017b) [25].

The use of such bioremediation products has made inroads into shrimp culture, significantly reducing the use of antibacterial and antibiotics in fish and shrimp culture, which was observed to be a significant positive development of aquaculture in the country. In Bangladesh aquaculture there are several reports of use of a wide variety of traditional as well as new compounds like geotox, green zeolite, zeolite, zeocare, lime, mega zeo, bio aqua, gastrap, aquanone, zeo-fresh, zeo prime, Mega zeo, Bio Aqua, Aquanone etc. are being used for the pond preparation and water quality management [17,28]. Aquanone was used for controlling unwanted fishes as well as other harmful aquatic animals. Jelani et al. (2012) [54] reported that lime, zeolite, fish toxin, insecticides and different fertilizers were used for the preparation and water quality management in Noakhali district, Bangladesh. Besides these Bio-ox, best oxygen, oxygen plus, oxyflow, oxygold, oxygrow, oxylife, oxymax, oxymore and oxyplus were used for increasing oxygen concentration in pond [17].

Antimicrobial resistance in traditional fish farming systems in temperate waters has been intensively studied [34]. In many developing countries the use of antimicrobial drugs for treating people and animals is unregulated. Studies have shown a direct relationship between antibiotic use in food animals and the emergence of antibiotic resistance in human and animal pathogens. The use of antibiotics as feed additives in food animals has been cited as one of the reasons for the development of Antibiotic Resistant Bacteria (ARB) in the environment [55]. A high incidence of bacteria resistant to the antimicrobials used in aquaculture, including multiply resistant bacteria, has been found in fish farms and the surrounding aquatic environments $[55,56]$ Furthermore, residues of antimicrobials have been found in the sediments of marine fish farms [57]. With above concern, FDA's Center for Veterinary Medicine has identified a number of "low regulatory priority aquaculture drugs." These compounds have undergone review by the Food and Drug Administration and have been determined to be new animal drugs of low regulatory priority (USFDA, 2017) [58]. In India, the emphasis so far has been on improv- 


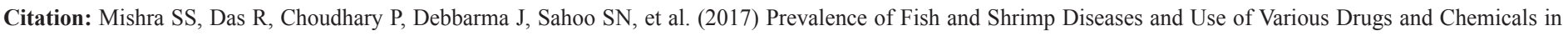
Indian Aquaculture for Disease Management. J Fish Aqua Dev: JFAD-129. DOI: 10.29011/JFAD-129. 100029

ing shrimp farming techniques to minimize their environmental impact, as well as to extend the sustainability through technology options. Now more efforts are needed to increase shrimp production with adoption of bio-secure measures for reducing production losses, as has been adopted in shrimp producing countries [59]. For increased export earnings, private sector participation in solving the issues of quality management, inspection, monitoring and verification procedures among shrimp manufacturers/exporters has to be encouraged including implementation of Hazard Analysis and Critical Control Point (HACCP) quality system, which is required for all shrimp exported to the EU and the U.S.A [7].

Based on WHO-OIE recommendations and USFDA guidelines several countries have made regulations on use of various drugs/ chemicals/ antibiotics in aquaculture and some of the products which have application in human health have been banned for use in aquaculture. European Union, US FDA and Japan have notified zero level drug residues of selected antibiotic viz. Chloramphenicol, Furazolidine Nalidixic acid Neomycine Oxolinic acid (quinoline compound), Oxy tetracycline, Tetracycline and Sulphamethaxazole/Trinethoprim (Sulphonamide) in the imported shrimp $[49,55]$. Accordingly, on the basis of Government of India notification, MPEDA and Coastal Aquaculture Authority (CAA) has banned use of various drugs, chemicals, antibiotics and other formulations in aquaculture, which includes use of Chloramphenicol, Nitrofurans, Neomycin, Nalidixic Acid, Sulphamethoxazole, Sulfonamide drugs, etc. $[25,60]$. However, this does not mean all antibiotics not in the list are permitted for use. It is therefore essential to follow international guidelines, specifically those advocated by FAO and USFDA and followed by many farms (Figure 6a and 6b).

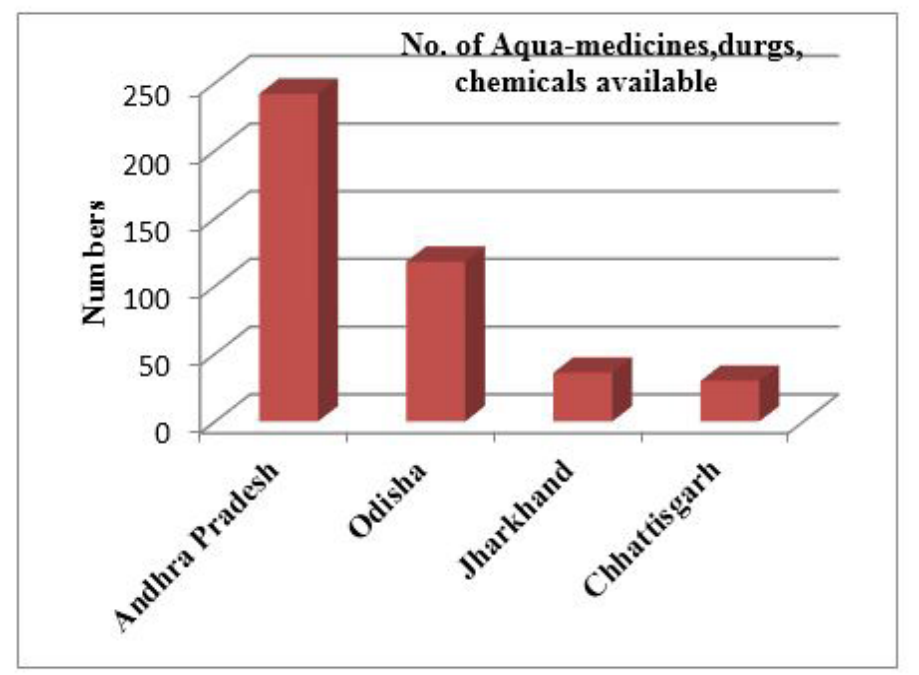

Figure 6a: Information received on different drugs, chemicals, antibiotics and microbiological formulation commercially available in four aquaculture dominant states in India, during the present survey.

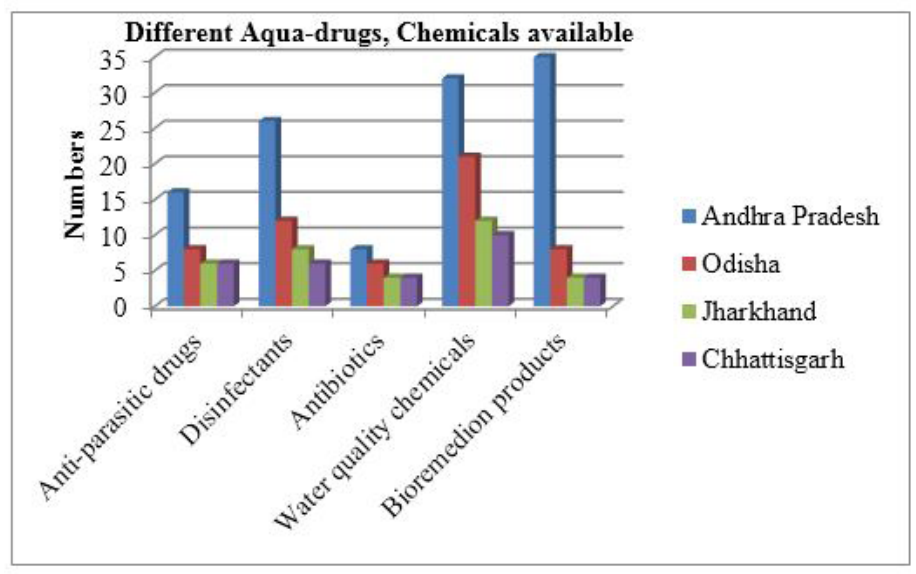

Figure 6b: Different categories of drugs, chemicals, antibiotics and microbiological formulation commercially available in four aquaculture dominant states in India, during the present survey.

In the present investigation, it was observed that chemical needs were less in fish culture than in shrimp culture. While farmers in fish culture normally spend $5-10 \%$ of their total investment in use of various drugs, chemicals vitamins, probiotics etc. in pond culture, a shrimp farmer often use $25-30 \%$ of total cost in pond management. This is because of high value produce shrimp, which fetch very good price US\$ 8-10 at international market. With high risk, the profit margin in shrimp farming is nearly $25-30 \%$, which in fish farming it is only $10-15 \%$. Again, it was observed that in those four states, use of drugs and chemicals have been minimum in some modified extensive and semi-intensive culture ponds and it is limited to only addition of lime, manure (Cow dung/ poultry wastes), lime and some fertilizes like DAP and Urea. As reported by many famers in all regions, compared to previous years the use of antimicrobials and antibiotics has been significantly reduced to almost 50-70 \% and it has been replaced by probiotics which were mainly used in water remediation and feed additives. Considering negative impact of chemicals use in shrimp culture, specifically their impact on digestive organs, use of liver tonics, gut enzymes, vitamins and minerals has significantly increased. Again, there has been growing concern of drug residues, specifically antibiotics and pesticides in shrimp tissue. There were several instances, when Indian shrimp consignment at international market were rejected and destroyed due to above reasons, leading to huge loss for the farmers. In our survey, it was observed that, while due care has been taken in some areas to minimize chemical use in fish and shrimp culture, some farmers in Andhra Pradesh and Odisha have adopted innovative method of organic aquaculture, without addition of any chemicals, drugs or chemical fertilizers. Use of " Jivamrutam" and "Traditional medicines" are some of the examples of organic method of disease control programme in aquaculture 


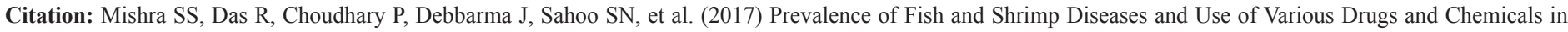
Indian Aquaculture for Disease Management. J Fish Aqua Dev: JFAD-129. DOI: 10.29011/JFAD-129. 100029

being adopted by some famers. The initial trials a have shown encouraging results with almost equal level of production and now steps are being taken to popularize organic fish and shrimp culture in other parts.

\section{Conclusion}

Aquaculture is a fast-growing food production sector and now represents the fastest growing agricultural industry in India with significant growth in last few decades. The phenomenal growth of aquaculture sector both in fish and shrimp production has caused some unwarranted activities including emergence and spread of diseases in aquaculture adversely affecting growth of the sector [11]. To protect cultured fish and shrimp, farmers are in practice of using a wide range of aqua-medicines, drugs and chemicals in aquaculture to control production loss. Besides aquaculture drugs and chemicals are also used in pond construction, soil and water management and various other aquaculture activities. Furthermore, the medicines or drugs used in veterinary practices and agriculture crop management, are also used in aquaculture. Most of the farmers in the region are unaware of the product they use in culture systems and they mostly go by the advice of local consultants or experts and representatives of feed manufacturing companies or drug dealers. There needs an urgent step to be taken by local authorities to discourage such unwarranted activities as serious concern has been raised by different international organizations over misuse or abuse of these chemicals, often leading to development of Antimicrobial Resistance (AMR). Like in India, in many developing countries the use of antimicrobial drugs for treating people and animals is unregulated. Studies have shown a direct relationship between antibiotic use in food animals and the emergence of antibiotic resistance in human and animal pathogens. The use of antibiotics as feed additives in food animals has been cited as one of the reasons for the development of Antibiotic Resistant Bacteria (ARB) in the environment [55]. Therefore, global efforts are essential to promote prophylactic use of antibiotics more judiciously in aquaculture and in other animals in order to verify the fact that unrestricted use of antibiotics is detrimental to fish, terrestrial animals, human health, food security problems and environmental hazards due to development of antimicrobial resistance $[16,61]$. There is some sign of relief that in last decade, there has been drastically reduction in use of antibiotics in aquaculture and most farmers are now dependent on microbial based probiotics and bioremediation products, while some farmers have successfully adopted organic fish culture. As Government is going to implement "National aquaculture Policy" there is scope of positive and sustainable development of aquaculture sector in India.

\section{Acknowledgment}

All the authors are grateful to State Fisheries Department of Govt. of Andhra Pradesh, Odisha, Jharkhand and Chhattisgarh for cooperation and help during survey work and all states respective dealers, retailers and distributors of aqua drugs and chemicals for providing base line information on subject during survey work. Authors are also thankful to ICAR for financial support in form of "Network project on Fish Health" and Director ICAR-CIFA for all kind of necessary support to carry out the work.

\section{References}

1. de Jong, Jelte (2017) Aquaculture in India, Report Rijksdienst voor Ondernemend Nederland.

2. Vijayan KK, Kumar S, Alavandi SV (2017) Emerging pathogens in Brackish water aquaculture and challenges in aquatic health management. In: Proceedings of International Symposium on aquatic Animal Health and Epidemiology for sustainable Asian Aquaculture, April 2021, 2017, ICAR-National Bureau of Fish Genetic Resources, Lucknow, India: $140-144$

3. NFDB (National Fisheries Development Board) (2017) About Indian Fisheries, National Fisheries Development Board, Department of Animal Husbandry, Dairying \& Fisheries, Ministry of Agriculture and Farmers Welfare, Government of India.

4. Kumar P, Sanjay K, Sudhakar D, Kumar SS. Himabindu (2015) An Overview of Fisheries and Aquaculture in India. Agro Economist 2: 1-6.

5. DAHDF (2017) Blue Revolution, Press Information Bureau, Department of Animal Husbandry, Dairying \& Fisheries, Ministry of Agriculture and Farmers Welfare, Government of India.

6. Bondad-Reantaso MG, Subasinghe RP, Arthur JR, Ogawa K, Chinabut $\mathrm{S}$, et al. (2005) Disease and health management in Asian aquaculture. Veterinary Parasitology 132: 249-272.

7. Kalaimani N, Ravisankar T, Chakravarthy N, Raja S, Santiago TC, et al. (2013) Economic Losses due to Disease Incidences in Shrimp Farms of India, Fishery Technology 50: 80-86.

8. MPEDA (2016) State-wise aqua culture productivity: Area utilized and production of Tiger Shrimp during 2015-16, The Marine Products Export Development Authority, Ministry of Commerce \& Industry, Government of India, Kochi, Kerala.

9. Aqua Aquaria India (2017) Aquaculture Production in India.

10. Mishra SS, Das, Rakesh, Choudhary P, Debbarma J, Sahoo SN, et al. (2017c) Present status of Fisheries and Impact of Emerging Diseases of Fish and Shellfish in Indian Aquaculture, Journal of Aquatic Research and Marine Sciences (open access), (Under publication).

11. Walker PJ, Winton JR (2010) Emerging viral diseases of fish and shrimp. Vet Res 41: 51

12. GESAMP (1997) Joint Group of Experts on the Scientific Aspects of Marine Environmental Protection. Towards safe and effective use of chemicals in coastal aqua culture. Respective Studies, (IMO/ FAO/ UNESCO/ IOC// WMO/ WHO/ IAEA/ UN/ UNEP 65: 40.

13. Pathak SC, Ghosh SK, Palanisamy K (2000) The use of chemicals in aquaculture in India. In: J. R. Arthur, C. R. Lavilla-Pitogo, \& R. P. Subasinghe (Eds.) Use of Chemicals in Aquaculture in Asia: Proceedings of the Meeting on the Use of Chemicals in Aquaculture in Asia 20-22 May 1996, Tigbauan, Iloilo, Philippines: 87-112. 
Citation: Mishra SS, Das R, Choudhary P, Debbarma J, Sahoo SN, et al. (2017) Prevalence of Fish and Shrimp Diseases and Use of Various Drugs and Chemicals in Indian Aquaculture for Disease Management. J Fish Aqua Dev: JFAD-129. DOI: 10.29011/JFAD-129. 100029

14. Subasinghe RP, Barg U, Tacon A (1996) Chemicals in Asian aquaculture: need, usage, issues and challenges. In: Use of Chemicals in Aquaculture in Asia. Arthur, J.R., C.R. Lavilla-Pitogo, R. P. Subasinghe (eds). Southeast Asian Fisheries Development Center, Aquaculture Department Tigbauan, Iloilo, Philippines: 1-6.

15. FAO (2005) Responsible Use of Antibiotics in Aquaculture. edited by FAO Fisheries Technical Paper. No.469. Rome Italy.

16. OIE (1999) European Scientific Conference on The Use of Antibiotics in Animals-Ensuring the Protection of Public Health. Paris 24-26.

17. Mohammad AM, MdA Rahman. Hossain MB, Zillur RMd (2014) Aquaculture Drugs Used for Fish and Shellfish Health Management in the South-western Bangladesh. Asian Journal of Biological Sciences 7 : 225-232.

18. Chawdhury AKJ, Saha D, Hossain MB, Shamsuddin M, Minar MH (2012) Chemicals Used in Freshwater Aquaculture with Special Emphasis to Fish Health Management of Noakhali, Bangladesh. African Journal of Basic \& Applied Sciences 4: 110-114.

19. Faruk MAR, Alam MJ, Sarker MMR, Kabir MB (2004) Status of fish disease and health management practices in rural freshwater aquaculture of Bangladesh. Pakistan Journal of Biological Science 7: 20922098.

20. Faruk MAR, Ali MM, Patwary ZP (2008) Evaluation of the status of use of chemicals and antibiotics in freshwater aquaculture activities with special emphasis to fish health management. J Bangladesh Agric Univ 6: 381-390.

21. Andrews S (2015) India's Shrimp Aquaculture Industry Remains Hopeful Despite Onset of Disease, The Fish site.

22. Rajendran KV, Shivam S, Ezhil Praveena P, Rajan JS, Kumar JS, et al. (2016) Emergence of Enterocytozoon hepatopenaei (EHP) in farmed Penaeus (Litopenaeus) vannamei in India. Aquaculture 454: 272-280.

23. Mishra SS, Rakesh D, Dhiman M, Choudhary P, Debbarma J, et al. (2017a) Present Status of Fish Disease Management in Freshwater Aquaculture in India: State-of the- Art-Review. Journal of Aquaculture \& Fisheries (Herald open Access) 1: 1-9.

24. Sahoo PK, Mohanty J, Garnayak JSK, Mohanty BR, Banya K, et al. (2013) Estimation of loss due to argulosis in carp culture ponds in India. Indian J Fish 60: 99-102.

25. Mishra SS, Das R, Das BK, Choudhary P, Rathod R, et al. (2017b) Status of Aqua-medicines, Drugs and Chemicals Use in India: A Survey Report. Journal of Aquaculture and Fisheries 1: 1-15.

26. Farhaduzzaman AM, Alam MM, Hossain M, Hussain M, Rahman AMH (2010) Prevalence of Parasites in the Indian Major Carp, Labeo rohita (Hamilton) in Rajshahi, Bangladesh. Univ j zool Rajshahi Univ 28: 6568.

27. Sandeep P, Devi BC, Kumar KP (2016) Present status of Parasitic and Bacterial diseases in Fresh Water Fish Seed Farms in East Godavari District, Andhra Pradesh. International J Applied and Pure Science and Agriculture 2: 117-121

28. Sharker MdR, Sumi KR, Alam MdJ, Rahman MdM, Ferdous Z, et al. (2014) Drugs and chemicals used in aquaculture activities for fish health management in the coastal regions of Bangladesh. International Journal of Life Sciences Biotechnology and Pharma Research 3: $50-58$.
29. Costello BMJ, Grant A, Davies IM, Cecchini S, Papoutsoglou S, et al. (2001) The control of chemicals used in aquaculture. European Journal of Applied Ichthyology 17: 173-180.

30. Burridge L, Weis JS, Cabello F, Pizarro J, Bostick K (2010) Chemical use in salmon aquaculture: A review of current practices and possible environmental effects. Aquaculture 306: 7-23.

31. Ahmed K, Kumar WAG (2005) Handbook on Fish and crustacean diseases in the SAARC region. First edition, SAARC Agricultural Information Centre, Bangladesh: 53.

32. Das BK, Mishra SS (2014) Diseases in Freshwater aquaculture, In: Training Manual on Model training course on Preventive health management practices in freshwater aquaculture, ICAR-Central Institute of Freshwater aquaculture, Bhubaneswar, Odisha: 1-17.

33. Mohanty BR, Sahoo PK (2007) Edwardsiellosis in fish: a brief review. J Biosci 32: 1331-1344.

34. Mitchell SK, James ML (2008) Risks to aquatic organisms posed by human pharmaceutical use. Sci Total Environ 389: 329-339.

35. Lucy T (2015) New Shrimp Disease Effecting India's Shrimp Production, The Fish Site, Health Biosecurity Post-Harvest Economics.

36. Srinivas D, Venkatrayalu Ch, Laxmappa B (2016) Identifying diseases affecting farmed Litopenaeus vannamei in different areas of Nellore district in Andhra Pradesh, India. International Journal of Fisheries and Aquatic Studies 4: 447-451.

37. Chowdhury AA, Uddin MdS, Vaumi S, Asif AA (2015) Aqua drugs and chemicals used in aquaculture of Zakigonj upazilla, Sylhet, Asian Journal of Medical and Biological Research 1: 336-349.

38. Sahoo PK, Goodwin AE (2012) Viruses of Freshwater Finfish in the Asian-Pacific Region. Indian Journal of Virology 23: 99-105.

39. Sahoo PK, Pradhan PK, Sundaray JK, Lal KK, Swaminathan TR (2017) Present Status of freshwater fish and shellfish diseases in India. In: Proceedings of International Symposium on aquatic Animal Health and Epidemiology for sustainable Asian Aquaculture, April 2021, 2017, ICAR-National Bureau of Fish Genetic Resources, Lucknow, India: 27-29.

40. Azad IS, Shekhar MS, Thirunavukkarasu AR, Poornima M, Kailasam $M$, et al. (2005) Nodavirus infection causes mortalities in hatchery produced larvae of Lates calcarifer: first report from India. Dis Aquatic Org 63: 113-118

41. Binesh CP, Jithendran KP (2013) Genetic characterization of betanodavirus isolates from Asian seabass Lates calcarifer (Bloch) in India Arch Virol 158: 1543-1546

42. dailyhunt (2017) Tilapia Lake virus spread to fish in Andhra, Kerala,Tamil Nadu, daily hunt.

43. Lightner DV (1996) Epizootiology, distribution and the impact on international trade of two penaeid shrimp viruses in the Americas. Rev Sci Tech Off Int Epizoot 15: 579-601.

44. Karunasagar I, Otta SK, Karunasagar I (1997) Histopathological and bacteriological study of white spot syndrome of Penaeus monodon along west coast of India. Aquaculture 153: 9-13

45. Mishra SS (1996) Prawn disease epizootics in India and its remedial measures. In: Proceedings of National workshop on fish and prawn disease epizootics and quarantine adoption in India, Central Inland Fisheries Research Institute, Barrackpore, Kolkata, West Bengal 9: 16-25. 


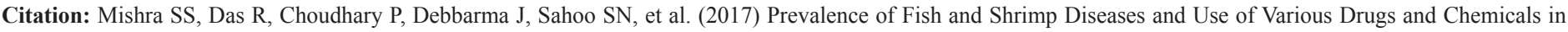
Indian Aquaculture for Disease Management. J Fish Aqua Dev: JFAD-129. DOI: 10.29011/JFAD-129. 100029

46. Algarswami K (1995) Status report on shrimp disease outbreak in coastal aquaculture farms on the east coast of India during 1994-1995, for the Technical Committee, Government of India, Ministry of Agriculture, New Delhi.

47. Flegel TW (1996) A turning point for sustainable aquaculture: The white spot virus crisis in Asian shrimp culture. Aquaculture Asia, JulySeptember 1996, Bangkok: NACA 1: 29-34.

48. Mana SK, Das BK (2017) Fish Health Management in Freshwater Cage Culture, in: Souvenir- National Seminar on Strategies, innovations and sustainable management for enhancing coldwater fisheries and Aquaculture", ICAR- Directorate of Cold Water Fisheries Research, Bhimtal, Nainital, Uttarakhand, India: 31-36.

49. Surendran PK (2002) Antibiotic residues in farmed shrimp- a major hazard, Technical paper 26. In: Winter school on "Recent advances in diagnosis and management of diseases in mariculture, 7-27 Nov. 2002, ICAR-Central Marine Fisheries Research Institute, Cochin, Kerala, India.

50. Joshua K, Sujathat A, Ramana LV, Carolin E, Supraba V (2002) Use of various chemicals in shrimp hatcheries and its sustainability in hatchery technology. Paper presented in National Workshop on Aquaculture Drugs, 18-20 Jan. 2002. CFDDM, Cochin University of Science and Technology, Cochin, Kerala, India.

51. Sapkota A, Sapkota AR, Kucharski M, Burke J, McKenzie S, et al. (2008) Aquaculture practices and potential human health risks: current knowledge and future priorities. Environmental International 34: 1215-26.

52. FDA (2011) Aquaculture Drugs. In: Fish and Fishery Products Hazards and Controls Guidance, 183 -208, Rockville, USA: Center for Food Safety and Applied Nutrition.
53. Smitha P, Donlon J, Coynea R, Cazabon DJ (1994) Fate of oxytetracyline in a freshwater fish farm: influence of effluent treatment systems. Aquaculture 120: 319-325.

54. Jilani AK, Debasish S, Belal MH, Shamsuddin M, Minar MH (2012) Chemicals Used in Freshwater Aquaculture with Special Emphasis to Fish Health Management of Noakhali, Bangladesh. African Journal of Basic \& Applied Sciences 4: 110-114.

55. Aly SM, Albutti A (2014) Antimicrobials Use in Aquaculture and their Public Health Impact. J Aquac Res Development 5: 247.

56. Alderman DJ, Hastings TS (1998) Antibiotic use in aquaculture: development of antibiotic resistance-potential for consumer health risks. Int J Food Sci Technol 33: 139-155.

57. Samuelsen OB, Torsvik V, Ervik A (1992) Long-range changes in oxytetracycline concentration and bacterial resistance towards oxytetracycline in a fish farm sediment after a medication. Sci Total Environ 114: $25-36$

58. US FDA (2017) Approved Aquaculture Drugs, U.S. Food and Drug Administration.

59. Arthur JR, Subasinghe RP (2002) Potential adverse socio-economic and biological impacts of aquatic animal pathogens due to hatcherybased enhancement of inland open water systems and possibilities for their minimization. In: Primary Aquatic Animal Health Care in Rural, Small-Scale, Aquaculture Development (Arthur, JR, Phillips MJ, Subasinghe RP, Reantaso MB, MacRae IH Eds): FAO Fish. Tech 406: 113- 126 .

60. CAA (2017) Coastal Aquaculture Authority.

61. Cabello FC (2006) Heavy use of prophylactic antibiotics in aquaculture: a growing problem for human and animal health and for the environment. Environmental Microbiology 8: 1137-1144. 